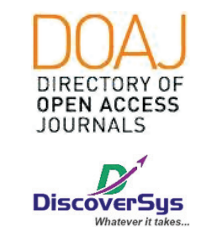

Published by DiscoverSys

\section{Faktor resiko gangguan pertumbuhan pada anak usia balita (1-5 tahun) di Rumah Sakit Ibu dan Anak (RSIA) Pucuk Permata Hati, Bali-Indonesia}

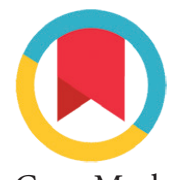

CrossMark

\author{
Made Diah Ari Bestari, ${ }^{* *}$ I Wayan Weta, ${ }^{2}$ Putu Aryani ${ }^{2}$
}

\section{ABSTRACT}

Background: Impaired growth is still a problem that is encountered in children, so the search for factors related to growth disorders is important to evaluate in order to make an early anticipation.

Method: This study used a case-control design conducted at Pucuk Permata Hati Child and Mother Hospital during the period February to April 2019. Sample search was done through consecutive methods. The search was carried out on the variables of child birth weight, maternal age at pregnancy, gestational age, hypertension conditions during pregnancy, history of abortion, maternal hemoglobin during pregnancy, placental disease (placental abruption or placenta previa), and breastfeeding. Data analysis using the help of SPSS version
25.0 software, chi-square test, logistic regression, and odds ratio calculation.

Results: This study found that there was a significant relationship between maternal age $\leq 20$ years, preterm pregnancy, hypertension during pregnancy, and placental disease during pregnancy as a risk factor that contributed to the occurrence of growth disorders in children $(O R>1 ; p<0.05)$. Then placental disease during pregnancy was the most important risk factor for growth disorders in children (aOR: 7.79; 95\% Cl: 1.79-75.97; $p=0.037$ ).

Conclusion: Age of preterm pregnancy, history of hypertension during pregnancy, and placental disorders are factors that play a role in the occurrence of growth disorders in children.
'Program Studi Pendidikan Dokter, Fakultas Kedokteran, Universitas Udayana

${ }^{2}$ Departemen/KSM Kedokteran Masyarakat-Kedokteran Pencegahan (DKM-KP), Fakultas Kedokteran, Universitas Udayana

*Correspondence to: Made Diah Ari Bestari, Program Studi Pendidikan Dokter, Fakultas Kedokteran, Universitas Udayana diaharibestari11@gmail.com

Diterima: 27-03-2019

Disetujui: 11-04-2019

Diterbitkan: 01-12-2019

Keywords: Toddlers, growing, growth risk factors.

Cite This Article: Bestari, M.D.A., Weta, I.W., Aryani, P. 2019. Faktor resiko gangguan pertumbuhan pada anak usia balita (1-5 tahun) di Rumah Sakit Ibu dan Anak (RSIA) Pucuk Permata Hati, Bali-Indonesia. Intisari Sains Medis 10(3): 643-648. D0I: 10.15562/ism.v10i3.460

\title{
ABSTRAK
}

Latar Belakang: Gangguan pertumbuhan masih menjadi masalah yang di jumpai pada anak, sehingga penelusuran faktor-faktor terkait gangguan tumbuh penting untuk dilakukan penelitian guna melakukan suatu antisipasi dini.

Metode: Penelitian ini menggunakan rancangan kasus-kontrol yang dilakukan pada RSIA Pucuk Permata Hati selama periode Februari hingga April 2019. Pencarian sampel dilakukan melalui metode konsekutif. Penelusuran dilakukan terhadap variabel berat lahir anak, usia ibu saat hamil, usia kehamilan, kondisi hipertensi selama kehamilan, riwayat abortus, hemoglobin ibu selama kehamilan, penyakit plasenta (solusio plasenta atau plasenta previa), dan pemberian ASI. Analisis data menggunakan bantuan perangkat lunak
SPSS versi 25.0, dilakukan uji chi-square, logistic regression, dan odds ratio calculation.

Hasil: Penelitian ini menemukan bahwa terdapat hubungan yang bermakna antara ujia ibu $\leq 20$ tahun, kehamilan preterm, hipertensi saat kehamilan, dan penyakit plasenta selama kehamilan merupakan faktor risiko yang berperan terhadap terjadinya gangguan tumbuh pada anak $(O R>1 ; p<0,05)$. Kemudian penyakit plasenta selama kehamilan merupakan faktor risiko yang paling berperan terhadap gangguan tumbuh pada anak (aOR: 7,79; IK 95\%: 1,79-75,97; $p=0,037$ ).

Simpulan: Usia kehamilan preterm, riwayat hipertensi selama kehamilan, dan gangguan plasenta merupakan faktor yang berperan dalam terjadinya gangguan tumbuh pada anak.

Kata kunci: Balita, tumbuh, faktor resiko pertumbuhan.

Cite Pasal Ini: Bestari, M.D.A., Weta, I.W., Aryani, P. 2019. Faktor resiko gangguan pertumbuhan pada anak usia balita (1-5 tahun) di Rumah Sakit Ibu dan Anak (RSIA) Pucuk Permata Hati, Bali-Indonesia. Intisari Sains Medis 10(3): 643-648. D0I: 10.15562/ism.v10i3.460

\section{PENDAHULUAN}

Hingga saat ini, masalah gizi pada balita masih merupakan masalah besar karena berkaitan erat dengan indikator kesehatan umum seperti tingginya angka kesakitan serta angka kematian bayi.
Kebutuhan anak balita pada proses pertumbuhan memerlukan zat zat makanan yang relative banyak dan kualitas tinggi dibutuhkan karena terjadinya proses pertumbuhan yang pesat. Masalah 
pertumbuhan merupakan aspek yang menjelaskan mengenai proses pembentukan seseorang, baik secara fisik maupun psikososial. ${ }^{1}$

Pertumbuhan menurut adalah perubahan yang bersifat kuantitatif, yaitu bertambahnya jumlah, ukuran, dimensi pada tingkat sel, organ maupun indivdu. Pertumbuhan tersebut tidak hanya melibatkan pertumbuhan dalam bentuk fisik, namun melibatkan juga ukuran dan struktur organ. ${ }^{2}$

Berdasarkan pengelompokan prevalensi gizi kurang menurut Organisasi Kesehatan Dunia (WHO), Indonesia tergolong sebagai negara dengan satuts kekuranagan gisi yang tinggi karena 5.119.935 balita dari 17.983.244 balita Indonesia $(28,47 \%)$ termasuk kelompok gizi kurang dan gizi buruk.

Kekurangan gizi ini diantaranya oleh meningktanya kecepatan pertumbuhan, serta semakin tngginya kebutuhan metabolisme, cadangan energi yang tidak mempuni, atau karena sistem fisiologis yang belum matang dengan sempurna. Gangguan pertumbuhan tersebut juga dapat diperparah apabila bayi hidup tanpa asupan gizi yang memadai karena ketidakmampuan keluarga sehingga berpotensi mengalami stunted. Anak stunted tanpa dukungan makan, kesehatan dan perawatan yang memadai akan tumbuh menjadi remaja yang stunted dan meningkatnya resiko penyakit kronis pada usia dewasa. Disamping itu, wanita stunted dengan status gizi yang buruk terutama pada masa kehamilan juga bersiko mengalami kematian maternal. ${ }^{3}$

Alasan dilakukan penelitian di RSIA Pucuk Permata Hati adalah dikarenakan rumah sakit ini merupakan rumah sakit yang khusu menangani masalah ibu dan anak. Sehingga, lebih terfokus dalam menagani kasus asalah pertumbuhan. Selain itu, masalah pertumbuhan merupakan masalah yang perlu dilakukan dengan deteksi dini sehinga dapat langsung mengambil dari populasi umum pada tiap pasien yang datang dan akan melakuakan konsultasi dan kontrol ke rumah sakit.

Deteksi pertumbuhan dimulai dengan penggunaan kurva pertumbuhan yang baku. Harapannya, dengan menilai pola pertumbuhan serta beberapa analisis pada faktor resiko yang berhubungan serta pemeriksaan tertentu, dapat dibedakan apakah terdapat gangguan pertumbuhan yang bersifat patologis atau bukan. Tujuan dari penelitian ini

\section{Tabel 1 Karakteristik subjek}

\begin{tabular}{lccc}
\hline Variabel & Kasus & Kontrol & p \\
\hline Usia (bulan) (Rerata \pm SD) & $16,33 \pm 4,72$ & $17,89 \pm 4,36$ & 0,312 \\
Jenis Kelamin & & & \\
Laki-laki & $10(58,8 \%)$ & $7(41,2 \%)$ & 0,317 \\
Perempuan & $8(42,1 \%)$ & $11(57,9 \%)$ & \\
\hline
\end{tabular}

adalah untuk mengetahu faktor-faktor risiko terkait gangguan tumbuh pada anak di RSIA Pucuk Permata Hati.

\section{METODE}

Penelitian ini menggunakan rancangan kasus kontrol, dimana terlebih dahulu dilakukan identifikasi pada kelompok kasus (anak dengan gangguan tumbuh) di RSIA Pucuk Permata Hati, kemudian untuk kelompok kontrol dicari pada populasi sehat. Penelitian dilakukan selama periode Februari hingga April 2019. Kriteria inklusi dalam penelitian ini adalah orang tua pasien bersedia dilakukan pemeriksaan pada anak dan mau meluangkan waktu untuk dilakukan wawancara terkait dengan riwayat kehamilan dan tumbuh anak. Kriteria eksklusi Pasien dengan kondisi patologis yang menyebabkan terjadinya gangguan tumbuh kembang seperti autism, sindroma down, cerebral palsy, dan distrofi muscular, pasien anak yang tidak kooperatif untuk dilakukan pemeriksaan. Kelompok kontrol dilakukan pengambilan pada populasi yang sehat. Sampel dilakukan pencarian melalui metode konsekutif, sampel yang memenuhi kriteria inklusi dan eksklusi akan langsung menjadi sampel dalam penelitian. Pengukuran tumbuh dilakukan menggunakan penilaian kurva z-score milik World Health Organization (WHO). Penelusuran faktor risiko yang dilakukan adalah berat lahir anak, usia ibu saat hamil, usia kehamilan, kondisi hipertensi selama kehamilan, riwayat abortus, hemoglobin ibu selama kehamilan, penyakit plasenta (solusio plasenta atau plasenta previa), dan pemberian ASI eksklusif melalui wawancara dan penelusuran riwayat asuhan ante natal.

Analisis statistik dalam penelitian ini menggunakan bantuan perangkat lunak SPSS versi 25.0, uji chi-square test dan perhitungan rasio odds untuk mengetahui hubungan antara faktor-faktor risiko yang dilakukan penelitian terhadap gangguan tumbuh pada anak. Kemudian uji regresi logistic digunakan untuk mencari faktor risiko yang paling berperan dalam terkadinya gangguan tumbuh pada anak. Seluruh nilai uji dianggap bermakna apabila nilai $\mathrm{p}<0,05$.

\section{HASIL PENELITIAN}

Penelitian ini menggunakan 36 sampel penelitian (18 anak dengan gangguan tumbuh yaitu failure to thrive, dan 18 anak normal) data karakteristik penelitian dapat dilihat pada tabel 1. Rerata usia pada kelompok kasus adalah 16,33 tahun dan rerata usia pada kelompok kontrol adalah 18,89 tahun, nilai $\mathrm{p}$ menunjukkan $\mathrm{p}=0,312$ yang berarti bawah tidak terdapat perbedaan karakteristik usia antara 
Tabel 2 Analisis faktor-faktor risiko gangguan tumbuh pada anak

\begin{tabular}{|c|c|c|c|c|c|c|}
\hline \multirow{2}{*}{ Faktor Risiko } & & \multicolumn{2}{|c|}{ Gangguan Pertumbuhan } & \multirow[b]{2}{*}{ OR } & \multirow[b]{2}{*}{ IK 95\% } & \multirow[b]{2}{*}{$\mathbf{p}$} \\
\hline & & $\mathrm{Ya}(\mathrm{n}, \%)$ & Tidak (n,\%) & & & \\
\hline \multirow[t]{2}{*}{ Usia ibu saat hamil } & $\leq 20$ tahun & $8(44,4 \%)$ & $4(22,2 \%)$ & \multirow{2}{*}{2,80} & \multirow{2}{*}{$1,65-11,92$} & \multirow{2}{*}{$0.047^{\star}$} \\
\hline & $>20$ tahun & $10(55,6 \%)$ & $14(77,8 \%)$ & & & \\
\hline \multirow[t]{2}{*}{ Berat Badan Lahir } & BBLR $<2500$ & $7(38,9 \%)$ & $7(38,9 \%)$ & \multirow{2}{*}{1,00} & \multirow{2}{*}{$0,26-3,82$} & \multirow{2}{*}{1,00} \\
\hline & Normal & $11(61,1 \%)$ & $11(61,1 \%)$ & & & \\
\hline \multirow[t]{2}{*}{ Kehamilan } & Preterm & $6(33,3 \%)$ & $5(27,8 \%)$ & \multirow{2}{*}{1,30} & \multirow{2}{*}{$1,02-5,39$} & \multirow{2}{*}{$0,041^{*}$} \\
\hline & Aterm & $12(66,7 \%)$ & $13(72,2 \%)$ & & & \\
\hline \multirow[t]{2}{*}{ Hipertensi saat kehamilan } & Ya & $7(38,9 \%)$ & $5(27,8 \%)$ & \multirow{2}{*}{1,65} & \multirow{2}{*}{$1,01-6,71$} & \multirow{2}{*}{$0,048^{\star}$} \\
\hline & Tidak & $11(61,1 \%)$ & $13(72,7 \%)$ & & & \\
\hline \multirow[t]{2}{*}{ Riwayat abortus } & Ya & $7(38,9 \%)$ & $4(22,2 \%)$ & \multirow{2}{*}{2,27} & \multirow{2}{*}{$0,51-9,59$} & \multirow{2}{*}{0,248} \\
\hline & Tidak & $11(61,1 \%)$ & $4(77,8 \%)$ & & & \\
\hline \multirow[t]{2}{*}{ Hb ibu saat kehamilan } & $<11 \mathrm{~g} / \mathrm{dl}$ & $4(22,2 \%)$ & $8(44,4 \%)$ & \multirow{2}{*}{0,35} & \multirow{2}{*}{$0,08-1,52$} & \multirow{2}{*}{0,157} \\
\hline & $>11 \mathrm{~g} / \mathrm{dl}$ & $14(77,8 \%)$ & $10(55,6 \%)$ & & & \\
\hline \multirow{2}{*}{$\begin{array}{l}\text { Penyakit plasenta (solusio atau } \\
\text { plasenta previa }\end{array}$} & Ya & $7(38,9 \%)$ & $3(16,7 \%)$ & \multirow{2}{*}{3,18} & \multirow{2}{*}{$1,66-15,14$} & \multirow{2}{*}{$0,037^{\star}$} \\
\hline & Tidak & $11(61,1 \%)$ & $15(83,3 \%)$ & & & \\
\hline \multirow[t]{2}{*}{ ASI } & Non eksklusif & $7(38,9 \%)$ & $9(50 \%)$ & \multirow{2}{*}{0,63} & \multirow{2}{*}{$0,16-2,39$} & \multirow{2}{*}{0,052} \\
\hline & Eksklusif & $11(61,1 \%)$ & $9(50 \%)$ & & & \\
\hline
\end{tabular}

${ }^{*}$ Signfikan $(\mathrm{p}<0,05)$

Tabel 3 Analisis regresi logistik

\begin{tabular}{lccc}
\hline Variabel & Adjusted OR & IK 95\% & p \\
\hline Usia ibu saat hamil & 9,37 & $0,91-96,26$ & 0,060 \\
BBLR (<2500 gram) & 1,73 & $0,03-91,65$ & 0,786 \\
Kehamilan Preterm (<37 minggu) & 1,22 & $1,03-45,51$ & $0,012^{*}$ \\
Riwayat hipertensi saat kehamilan & 3,05 & $1,40-23,16$ & $0,021^{\star}$ \\
Riwayat Abortus & 5,51 & $0,62-48,82$ & 0,125 \\
Hemoglobin Ibu rendah (<11 g/dl) & 0,11 & $0,01-1,158$ & 0,056 \\
Penyakit plasenta (solusia atau plasenta previa) & 7,79 & $1,79-75,97$ & $0,037^{\star}$ \\
ASI non eksklusif & 1,39 & $0,21-9,02$ & 0,728
\end{tabular}

${ }^{*}$ Signifikan $(\mathrm{p}<0,05)$

kelompok kasus dan kontrol. Berdasarkan jenis kelamin, laki-laki lebih banyak pada kelompok kasus (58,8\%), sedangkan perempuan lebih banyak pada kelompok kontrol (57,9\%), nilai p menunjukkan $p=0,317$ yang berarti tidak terdapat perbedaan karakteristik jenis kelamin antara kelompok kasus dan kelompok kontrol (Tabel 1).

Tabel 2, menunjukkan bahwa dari keseluruhan variabel yang dilakukan penelitian menunjukkan ujia ibu $\leq 20$ tahun, kehamilan preterm, hipertensi saat kehamilan, dan penyakit plasenta selama kehamilan merupakan faktor risiko yang berperan terhadap terjadinya gangguan tumbuh pada anak $(\mathrm{OR}>1 ; \mathrm{p}<0,05)$.

Seluruh hasil dari analisis bivariate akan dilajutkan pada permodelan regresi logistic untuk mengetahui faktor yang paling berperan dari keseluruhan faktor risiko yang ada terhadap gangguan tumbuh pada anak. Melalui analisis regresi logistik variabel kehamilan preterm, riwayat hipertensi selama kehamilan, dan penyakit plasenta selama kehamilan merupakan faktor risiko yang paling memiliki hubungan terhadap gangguan tumbuh pada anak $(\mathrm{aOR}>1, \mathrm{p}<0,05)$. Kemudian dapat diketahui bahwa penyakit plasenta selama kehamilan merupakan faktor risiko yang paling berperan terhadap gangguan tumbuh pada anak (aOR: 7,79; IK 95\%: 1,7975,97; $\mathrm{p}=0,037$ ) (Tabel 3).

\section{PEMBAHASAN}

\section{Usia ibu saat kehamilan}

Pada penelitian ini tidak ditemukan hubungan antara usia $\mathrm{ibu}<20$ tahun terhadap gangguan 
pertumbuhan pada anak. Penelitian lain yang dilakukan oleh Mamabolo dkk. ${ }^{5}$ di Provinsi Limpopo, Afrika selatan menemukan temuan yang serupa bahwa usia ibu $<20$ tahun bukan merupakan suatu faktor risiko untuk terjadinya gangguan tumbuh pada anak (OR: 0,72; IK95\%: 0,18-2,88), namun secara mengejutkan pada penelitian tersebut usia ibu $<20$ tahun justru memiliki pengaruh terhadap kejadian berat badan lebih pada anak.

Penelitian lain yang dilakukan oleh Nahagori dkk. ${ }^{6}$ pada 100 anak usia 5-24 bulan di Republik Kamerun menemukan bahwa anak dengan gangguan pertumbuhan lebih banyak ditemukan pada ibu dengan rerata usia 20 tahun. Usia ibu yang terlalu muda dikaitkan sebagai faktor yang berkontribusi dalam terjadinya berat lahir rendah pada bayi. Oleh karena kejadian berat bayi lahir rendah sangat dipengaruhi oleh berbagai faktor, dapat diasumsikan bahwa usia ibu yang terlalu muda mampu memberikan pengaruh terhadap status nutrisi dari anak. Terlebih lagi, ibu yang lebih muda cenderung memiliki pengetahuan yang kurang dan status pekerjaan belum begitu baik, sehingga hal tersebut berkontribusi terhadap gangguan tumbuh pada anak. ${ }^{7}$

\section{Berat badan lahir}

Pada penelitian ini tidak terdapat hubungan antara BBLR sebagai faktor risiko dari gangguan tumbuh pada anak. Penelitian lain yang dilakukan oleh Chopra dkk. ${ }^{8}$ terhadap 100 anak di Kwazulu, Afrika Selatan, menemukan bahwa BBLR (berat lahir <2500 gram) merupakan faktor risiko untuk terjadinya gangguan tumbuh pada anak (OR: 5,25 $p<0,001)$. Nutrisi yang rendah selama kehamilan akan berdampak pada suatu retardasi pertumbuhan intra uterin dan kemudian akan menjadi bayi dengan berat lahir rendah. Kondisi ini merupakan suatu masalah yang sangat umum dijumpai di negara berkembang.

Penelitian lain yang dlakukan oleh Adekanmbi dkk. ${ }^{4}$ mengenai gangguan tumbuh pada 7322 anak di Nigeria menemukan bahwa gangguan tumbuh cenderung lebih banyak pada anak dengan BBLR $(28,5 \%)$ dibandingkan dengan tidak BBLR $(25,3 \%)$ serta BBLR merupakan faktor risiko dari gangguan tumbuh (OR: 1,$21 ; \mathrm{p}<0,001)$.

\section{Riwayat hipertensi selama kehamilan}

Dalam penelitian ini menemukan adanya hubungan yang bermakna antara hipertensi sebagai faktor risiko dari gangguan tumbuh pada anak. Penelitian lain yang dilakukan oleh Li dkk. ${ }^{9}$ pada 548 ibu dengan preeklamisa menemukan bahwa orang dengan preeclampsia memiliki risiko 1,73 kali untuk mengalami kelahiran dengan berat badan lahir rendah.
Kegagalan adaptasi kardiovaskular yang menyebabkan hipertensi sistemik dan disfungsi endotel kemudian disertai dengan peningkatan permeabilitas glomerulus sehingga menyebabkan kebocoran makro molekul protein. Dari sisi lain hal tersebut juga menimbulkan keadaan patologi pada plasenta, yaitu kegagalan invasi trofoblas. Kegagalan tersebut menyebabkan vasokonstriksi dari arteri spiralis, sehingga menyebabkan kegagalan dilatasi dan iskemia plasenta. ${ }^{10}$ Kegagalan adaptasi kardiovaskular dan disfungsi endotel menyebabkan terjadinya kebocoran cairan dari intravascular dan interstisial yang bermanifestasi sebagai edema. Peningkatan permeabilitas glomerulus akan menyebabkan terjadinya protein urin. Kegagalan infasi trofoblas akan menyebabkan iskemia trofoblas pelepasan mediator inflamasi, dan vasokonstriksi yang berujung pada keadaan hipertensi. Seluruh mekanisme tersebut akan merujuk pada suatu keadaan yang disebut dengan preeklamsia yang ditandai dengan adanya hipertensi, proteinurin, dan edema pada kehamilan dimana keseluruhan dari hal tersebut akan menyebabkan vasokonstriksi dan aliran darah uteroplasenta yang berkurang.." Konsekuensi dari hal tersebut adalah pertumbuhan intra uterine yang juga terganggu sehingga menyebabkan kejadian BBLR yang lebih tinggi pada populasi dengan preeklamsia.

Hal ini didukung oleh studi yang dilakukan oleh Dowel dkk. ${ }^{12}$ terhadap 25544 kelahiran menemukan bahwa preeklamsia merupakan faktor risiko untuk terjadinya suatu kondisi BBLR (OR: 1,98; $\mathrm{p}<0,001)$. Bayi dengan BBLR cenderung memiliki masalah dalam pertumbuhannya dan lebih rentan untuk mengalami suatu penyakit ataupun infeksi sehingga hal ini berdampak terhadap pertumbuhan dari anak tersebut.

\section{Riwayat Abortus}

Abortus dalam penelitian ini tidak memiliki hubungan yang bermakna sebagai faktor risiko dari gangguan tumbuh pada anak. Abortus menyebabkan suatu pendarahan oleh karena adanya cidera jaringan pada bagian endometrium. Pada fase lanjut pendarahan yang terjadi akan menyebabkan suatu kemungkinan anemia. Kehamilan yang diawali dengan karakteristik anemia akan cederung menyebabkan suatu gangguan dalam pertumbuhan dan perkembangan bayi. Sebagai konsekuensi dari hal tersebut maka sangat mungkin untuk terjadi suatu kelahiram BBLR. Dimana kelahiran BBLR merupakan suatu faktor risiko yang memang sangat mendukung terhadap terjadinya gangguan tumbuh pada anak..$^{13}$

\section{Anemia}

Anemia selama kehamilan dalam penelitia ini tidak memiliki suatu hubungan yang bermakna dalam 
terjadinya gangguan tumbuh pada anak. Pada kehamilan yang normal konsentrasi hemoglobin ibu menurun pada 20 minggu pertama kehamilan, dan tetap konstan hingga usia 30 minggu. Adanya anemia selama masa kehamilan dikaitkan dengan peningkatan risiko dari BBLR dan prematuritas. Steer dkk. ${ }^{14}$ Mengungkapkan bahwa kejadian BBLR paling rendah pada nilai $\mathrm{Hb}$ 9.5-10.5 dan secara berkebalikan $\mathrm{Hb}$ diatas 12 akan meningkatkan risiko BBLR dan prematuritas. Secara langsung anemia pada kehamilan memang tidak menimbulkan dampak langsung terhadap gangguan tumuh, namun risiko prematuritas yang ditimbulkan kemudian hal tersebut menjadi faktor yang mempermudah anak untuk mengalami penyakit infeksi ataupun malabsorbsi sehingga hal tersebut yang berdampak terhadap gangguan pertumbuhan pada anak. ${ }^{15}$

\section{ASI dan gangguan tumbuh}

Pada penelitian ini tidak ditemukan adanya hubungan yang bermakna antara pemberian ASI non eksklusif sebagai faktor risiko dari gangguan tumbuh pada anak. Penelitian lain yang mengkaji mengkaji mengenai gangguan pertumbuhan pada anak yang dilakukan oleh Nahagori dkk. ${ }^{6}$ menemukan bahwa pemberian ASI tidak memiliki hubungan terhadap gangguan tumbuh pada anak.

Penelitian deskriptif lain yang dilakukan oleh Devi dkk. ${ }^{16}$ di 7 Provinsi di Indonesia menemukan temuan yang berbeda. Hanya sedikit dari Ibu yang memberikan ASI secara eksklusif pada anaknya, dari total 4378 anak yang mengalami gangguan tumbuh, hanya 50 anak yang mendapatkan ASI eksklusif $(1,1 \%)$ dan $98,9 \%$ tidak mendapatkan ASI eksklusif.

ASI sangat dibutuhkan pada bayi dalam perkembangan otak dan tubuhnya. Didalam ASI terdapat tiga unsur protein yang jauh lebih tinggi dibandingkan dengan susu sapi biasa, sehingga dampaknya masih akan terasa ketika bayi sudah beranjan lebih besar. Selain itu ASI juga dapat menjaga kekebalan tubuh anak oleh karena susu mengandung zat antibodi yang sangat berguna dalam kekebalan tubuh. ${ }^{16,19}$

\section{Kehamilan preterm}

Dalam penelitian ini kehamilan pretem memiliki hubungan yang bermakna terhadap gangguan tumbuh pada anak. Bayi preterm sangat sering mengalami gangguan tumbuh oleh karena faktor maternal, plasenta. Studi yang dilakukan oleh Gonzales dkk. ${ }^{17}$ menunjukkan bahwa bayi yang lahir preterm cenderung memiliki tinggi yang lebih rendah dibandingkan dengan bayi yang lahir cukup bulan. Studi yang dilakukan oleh Santos dkk..$^{18}$ menemukan bahwa anak yang lahir diantara usia kehamilan 34-36 minggu memiliki risiko yang meningkat terhadap ganguan tumbuh dan juga berat badan kurang pada usia 12 hingga 24 bulan yang dibandingkan dengan kelompok kontrol (anak yang lahir cukup bulan). Gangguan tumbuh yang terjadi sangat sering dikaitkan dengan masalah-masalah terkait dengan penyakit infeksi, gangguan makan, sindroma malabsorbsi yang terjadi pada anak dengan kelahiran preterm sehingga hal tersebut yang menjadi penyebab gangguan tumbuh pada anak. ${ }^{15}$

\section{Kelainan plasenta}

Dalam penelitian ini kelainan plasenta yang dimaksudkan adalah plasenta previa atau solusio plasenta, ditemukan adanya hubungan yang bermakna antara kelainan plasenta selama hamil terhadap gangguan tumbuh pada anak. Gangguan plasenta ataupun korda umbilikalis seperti solusio plasenta, infark plasenta, hemangioma plasenta, plasenta previa dihubungkan dengan kejadian retardasi pertumbuhan dalam kandungan. Pada keseluruhan kasus terdapat penurunan aliran darah utero plasenta, oksigenasi fetus, dan mekanisme kompensatorik hemoglobin dalam darah. Hubungan utama dari kejadian gangguan plasenta terhadap gangguan tumbuh disebabkan oleh adanya risiko prematuritas yang ditimbulkan oleh karena adanya masalah pada plasenta. ${ }^{15}$

\section{Kelemahan dalam penelitian}

Penelitian ini menggunakan rancangan case-control dengan jumlah sampel yang terbatas, sehingga ini menjadi suatu kelemahan terkait dengan generalisasi hasil penelitian ke populasi. Kemudian ada kemungkinan terjadinya suatu recall bias oleh karena penelitian ini menggunakan rancangan retrospektif dalam pengambilan datanya.

\section{SIMPULAN}

Usia kehamilan preterm, riwayat hipertensi selama kehamilan, dan gangguan plasenta merupakan faktor yang berperan dalam terjadinya gangguan tumbuh pada anak. Kemudian penyakit plasenta selama kehamilan merupakan faktor yang paling berperan dalam terjadinya gangguan tumbuh pada anak.

\section{KONFLIK KEPENTINGAN}

Penulis menyatakan tidak memiliki konflik kepentingan terkait publikasi dari penelitian ini

\section{PENDANAAN}

Penelitian ini tidak mendapatkan pendanaan oleh pemerintah ataupun lembaga swasta privat lainyya. 


\section{ETIKA DALAM PENELITIAN}

Penelitian ini telah mendapatkan persetujuan dari Komite Etik, Fakultas Kedokteran Universitas Udayana/RSUP Sanglah Denpasar dengan nomer referensi 189/UN14.2.2.VII.14/LP/2018.

\section{DAFTAR PUSTAKA}

1. Glass HC, Costarino AT, Stayer SA, Brett CM, Cladis F, Davis PJ. Outcomes for extremely premature infants. Anest Analg. 2015;120(6):1337-51

2. Soetjiningsih. Tumbuh kembang anak. Bagian Kesehatan Anak Fakultas Kedokteran Universitas Udayana Bali. Penerbit Buku Kedokteran EGC; 1995. p. 1-36.

3. Simbolon D. Berat Lahir dan Kelangsungan Hidup Neonatal. Jurnal Kesehatan Masyarakat Nasional. 2012;3(1):16-22.

4. Adekanmbi VT, Kayode GA, Uthman OA. Individual and contextual factors associated with childhood stunting in Nigeria: a multilevel analysis. Maternal \& Child Nutrition. 2011:45(1):1-16.

5. Mamabolo RL, Alberts M, Steyn NP, de Waal HAD, Levitt NS. Prevalence and determinants of stunting and overweight in 3-year-old black south African children residing in central region of Limpopo province, south Africa. Public Health Nutrition. 2005;8(5):501-508

6. Nagahori C, Tchuani JP, Yamauchi T. Factor associated with nutritional status in children aged 5-24 months in the republic of Cameroon. Nursing and Health Sciences. 2015;17:229-235.

7. Ayaya SO, Esamai FO, Rotich J, Olwambula AR. Socioeconomic factors predisposing under five-year-old children to severe protein energy malnutrition at the Moi Teaching and Referral Hospital, Eldoret, Kenya. East African Medical Journal. 2004;81:415-421

8. Chopra M, Risk factors for undernutrition of young children in a rural area of south Africa. Public Health Nutrition. 2003;6(7):645-652.

9. Li X, Zhang W, Lin J, Liu H, Yang Z, et al. Perterm birth, low birthweight, and small for gestational age among women with preeclampsia: does maternal age matter. Pregnancy and Hypertension. 2018;13:260-266.
10. Ngene N, Moodley J. 2018. Role of angiogenic factors in the pathogenesis and management of pre-eclampsia. Int $J$ Gynaecol Obstet;141(1):5-13.

11. James JL, Saghian R, Perwick R, Clark AR. 2018. Trophoblast plugs:impact on utero-placental haemodynamicx and spiral artery remodeling. Human Reproduction;7(1):1-12.

12. Dowell CM, Meijia GC, Preen DB, Segal L. Low birth weight and maternal incarceration in pregnancy: A longitudinal linked data study of Western Australian Infants. SSM-Population Health. 2019;7:100324.

13. Yang J, Savitz DA. The effect of vaginal bleeding during pregnancy on preterm and small-for-gestational-age births: US National Maternal and Infant Health Survey, 1998. Paediatr Perinat Epidemiol 2001;15(1):34-9.

14. Steer PJ. Maternal hemoglobin concentration and birth weight. Am J Clin Nutr 2000;71(Suppl 5):1285-7

15. Bernabe JV, Soriano T, Albaladejo R, Juarranz M, Calle ME, Martinez D, Rojas VD. Risk factors for low birth weight: a review. European Journal of Obstetrics \& Gynecology and Reproductive Biology. 2004;116:3-15.

16. Devi M. Analisis faktor-faktor yang berpengaruh terhadap status gizi balita di pedesaan. Teknologi dan Kejuruan. 2010;33(2):183-192.

17. Gonzalez Stager MA, Rodriguez Fernandez A, Munoz Valenzuela C, Ojeda Saez A, San Martin Navarrete A. Nutritional status of adolescents from a cohort of preterm children. Revista Chilena de Pediatria 2016: 87(4): 268-273

18. Santos IS, Matijasevich A, Domingues MR, Barros AJ, Victora CG, Barros FC. Late preterm birth is a risk factor for growth faltering in early childhood: a cohort study. BMC Pediatrics 2009: 9:71-79.

19. Pramitasari P, Sidiartha I, Pratiwi I. The effect of storage on energy, carbohydrate, fat, and protein content of breast milk. Bali Medical Journal. 2019;8(1):59-62. DOI:10.15562/bmj.v8i1.823

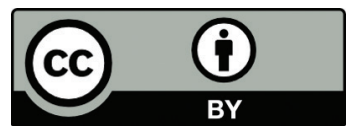

This work is licensed under a Creative Commons Attribution 